\title{
PENGARUH SWEDISH MASSAGE TERHADAP PENURUNAN TEKANAN DARAH PADA PASIEN HT DI RS RS AN-NISA TANGERANG TAHUN 2020
}

\section{Tri Widyaningrum}

STIKes YATSI Tangerang, Banten, Indonesia

Email: triwidya571@gmail.com

\begin{tabular}{|c|c|}
\hline INFO ARTIKEL & ABSTRAK \\
\hline $\begin{array}{l}\text { Tanggal diterima: } 2 \text { September } \\
2020 \\
\text { Tanggal revisi: } 10 \text { September } \\
2020 \\
\text { Tanggal yang diterima: } 25 \\
\text { September } 2020\end{array}$ & $\begin{array}{l}\text { Hipertensi dapat didefinisikan sebagai tekanan darah } \\
\text { persisten dimana tekanan sistoliknya diatas } 140 \mathrm{mmHg} \text { dan } \\
\text { tekanan diastolik diatas } 90 \mathrm{mmHg} \text {. Perubahan yang terjadi } \\
\text { salah satunya adalah tekanan darah meninggi diakibatkan } \\
\text { oleh meningkatnya resistansi dari pembuluh darah } \\
\text { perifer, sistolik normal kurang lebih } 170 \mathrm{mmHg} \text { dan }\end{array}$ \\
\hline $\begin{array}{l}\text { Kata kunci: } \\
\text { Tekanan darah; Hipertensi; } \\
\text { Swedish massage }\end{array}$ & $\begin{array}{l}\text { diastolik normal kurang lebih } 90 \text { mmHg. Swedish } \\
\text { Massage untuk menurunkan tekanan darah pada pasien } \\
\text { hipertensi Swedish massage merupakan suatu tehnik } \\
\text { massage yang berfokus pada relaksasi dan meningkatkan } \\
\text { sirkulasi darah dengan melibatkan otot. penggunaan } \\
\text { massage oleh perawat memiliki potensi secara signifikan } \\
\text { meningkatkan status kesehatan. Tujuan penelitian ini adalah } \\
\text { untuk mengetahui pengaruh Swedish massage terhadap } \\
\text { penurunan tekanan darah pada pasien hipertensi di ruang } \\
\text { rawat inap RS An-Nisa Tangerang Tahun 2020. Metode } \\
\text { penelitian yang digunakan dalam penelitian ini adalah quasi } \\
\text { eksperimental design : one group pre test and post test } \\
\text { design. Populasi dalam penelitian ini berjumlah } 60 \\
\text { responden. Tehnik yang digunakan untuk pengambilan data } \\
\text { adalah accidental sampling. Hasil penelitian : Berdasarkan } \\
\text { uji t-paired bahwa p-value < 0,05 maka dapat dinyatakan } \\
\text { Ho ditolak dan Ha diterima artinya terdapat pengaruh antara } \\
\text { Swedish massage terhadap penurunan tekanan darah pada } \\
\text { pasien hipertensi di ruang rawat inap RS An-Nisa } \\
\text { Tangerang Tahun 2020. Kesimpulan : ada pengaruh } \\
\text { Swedish massage terhadap penurunan tekanan darah pada } \\
\text { pasien hipertensi di ruang rawat inap RS An-Nisa } \\
\text { Tangerang Tahun 2020. }\end{array}$ \\
\hline
\end{tabular}

\section{Pendahuluan}

Hipertensi dapat didefinisikan sebagai tekanan darah persisten dimana tekanan sistoliknya diatas $140 \mathrm{mmHg}$ dan tekanan diastolik diatas $90 \mathrm{mmHg}$. Berdasarkan data Badan Kesehatan Dunia (WHO) memperlihatkan yang menderita hipertensi mencapai 50\% sedangkan yang diketahui dan mendapatkan pengobatan hanya $25 \%$ dan $12,5 \%$ yang terobati dengan baik. Prevalensi hipertensi di Indonesia tercatat mencapai $31,7 \%$ dari populasi pada usia 18 tahun keatas dan dari jumlah tersebut $60 \%$ penderita hipertensi akan menderita stroke (Riskesdas, 2016). Data

Dinas Kesehatan Banten, jumlah penderita hipertensi mencapai 31,7 persen, stroke $(8,3$ persen), penyakit jantung (7,2 persen), penyakit sendi (30,3 persen), asma $(3,5$ persen), diabetes mellitus (5,7 persen), tumor (4,3 persen), dan cedera akibat kecelakaan lalu lintas darat (4,0 persen).

Seseorang didiagnosa hipertensi jika tekanan darah lebih dari 140/100 MmHg. Sedangkan tekanan darah merupakan tekanan yang diberikan oleh darah terhadap dinding pembuluh darah arteri dengan satuan milimeter mercury $(\mathrm{MmHg})$ dan 
direkam dalam dua angka yaitu tekanan sistole dan diastole. Tekanan darah sistole adalah tekanan darah pada saat jantung memompa darah kedalam pembuluh nadi (saat jantung berdenyut). Sedangkan tekanan darah diastole adalah tekanan darah pada saat jantung mengembang dan menyedot darah kembali (pembuluh nadi mengempis kosong) (Intarti \& Khoriah, 2018).

Penyebab hipertensi pada lansia antara lain akibat kekakuan pada arteri, stres pada lansia dan riwayat hipertensi. Stres merupakan gangguan jiwa non spesifik yang merupakan faktor pemicu terjadinya suatu penyakit Mardiana, Y. \& Zelfino, 2014). Lansia akan mengalami perubahan fisik sesuai dengan tingkatan umur. Adapun perubahan-perubahan fisik menurut (Nugroho, Zuiderwijk, Janssen, \& de Jong, 2015). salah satunya adalah perubahan yang terjadi pada sistem kardiovaskular. Elastisitas dinding aorta menurun dengan bertambahnya usia. Disertai dengan bertambahnya kaliber aorta. Perubahan ini terjadi akibat adanya perubahan pada dinding media aorta dan bukan merupakan akibat dari perubahan intima karena aterosklerosis. Perubahan aorta ini menjadi sebab apa yang disebut isolated aortic incompetence dan terdengarnya bising pada apex cordis.

$$
\text { Penambahan usia tidak }
$$

menyebabkan jantung mengecil (atrofi) seperti organ tubuh lain, tetapi malahan terjadi hipertropi. Pada umur 30-90 tahun massa jantung bertambah $( \pm 1$ gram/tahun pada laki-laki dan $\pm 1,5$ gram/tahun pada wanita). Pada daun dan cincin katup aorta perubahan utama terdiri dari berkurangnya jumlah inti sel dari jaringan fibrosa stroma katup, penumpukan lipid, degenerasi kolagen dan kalsifikasi jaringan fibrosa katup tersebut. Daun katup menjadi kaku, perubahan ini menyebabkan terdengarnya bising sistolik ejeksi pada usia lanjut.
Ukuran katup jantung tampak bertambah. Pada orang muda katup antrioventrikular lebih luas dari katup semilunar. Dengan bertambahnya usia terdapat penambahan circumferensi katup, katup aorta paling cepat sehingga pada usia lanjut menyamai katup mitral, juga menyebabkan penebalan katup mitral dan aorta.

Perubahan ini disebabkan degenerasi jaringan kalogen, pengecilan ukuran, penimbunan lemak dan kalsifikasi. Kalsifikasi sering terjadi pada anulus katup mitral yang sering ditemukan pada wanita. Perubahan pada katup aorta terjadi pada daun atau cincin katup. Katup menjadi kaku dan terdengar bising sistolik ejeksi. Tekanan darah meninggi diakibatkan oleh meningkatnya resistansi dari pembuluh darah perifer, sistolik normal kurang lebih $170 \mathrm{mmHg}$ dan diastolik normal kurang lebih $90 \mathrm{mmHg}$.

Hipertensi pada lansia di Amerika mempunyai prevalensi yang tinggi pada usia 65 tahun didapatkan $60-80 \%$ atau sekitar lima puluh juta warga lansia Amerika mempunyai prevalensi tinggi untuk hipertensi (Robinson et al., 2016). Menurut (Depkes, 2016). pada golongan umur 55-64 tahun, penderita hipertensi pada pria dan wanita sama banyak. Dari beberapa penelitian tingginya prevalensi hipertensi sejalan dengan bertambahnya umur. Berdasarkan penelitian yang dilakukan di 6 kota besar seperti Jakarta, Padang, Bandung, Yogyakarta, Denpasar, dan Makasar terhadap usia lanjut (55-85), didapatkan prevalensi hipertensi sebesar 52,5\% ( Sarasaty, 2017).

Hipertensi dapat berakibat fatal apabila tidak mendapatkan penatalaksanaanyang tepat.

Penatalaksanaan hipertensi tidak selalu menggunakan obat- obatan. Beberapa penelitian menunjukkan bahwa pendekatan nonfarmakologis dapat dilakukan pada pasien hipertensi yaitu meliputi : teknik- 
teknik penurunan berat badan, pembatasan alkohol, natrium, dan tembakau, olahraga atau latihan yang berefek meningkatkan lipoprotein berdensitas tinggi, relaksasi yang merupakan intervensi wajib yang harus dilakukan pada setiap terapi hipertensi dan massage (Rizal Muttaqin, 2016).

Teknik penyembuhan hipertensi dapat melalui dua jenis yaitu pengobatan medis dan pengobatan tradisional. Masingmasing jenis pengobatan memiliki dampak yang berbeda. Penggunaan pengobatan medis dalam jangka waktu yang lama dapat menimbulkan kerusakan hati dan ginjal yang berdampak pada komplikasi. Oleh sebab itu, masyarakat kini beralih pada pengobatan tradisional. Macam dan jenis pengobatan tradisional bervariasi meliputi: konsumsi jamu atau sering disebut obat herbal, pengobatan melalui musik, yoga, relaksasi, imagery, pijat refleksi, pijat tengkuk (neck massage), dan hipnotherapi (Intarti \& Khoriah, 2018).

Hasil penelitian yang dilakukan oleh (Olney, 2015). mendapatkan hasil bahwa massage dapat menurunkan tekanan darah sistolik dan diastolik pada pasien hipertensi. Salah satu massage yang bisa dilakukan adalah Swedish massage yaitu massage dengan bentuk klasik tehnik pijat barat dengan metode melakukan manipulasi jaringan lunak dengan lima gerakan antaralain effleurage, petrisage, friction, tapotement dan vibration. Penelitian Koq (2010) yang menggunakan Swedish massage dengan tekanan ringan hingga sedang dan dilakukan 4 kali selama seminggu dihasilkan rata-rata tekanan darah menurun setelah dilakukan massage. Swedish massage sebagai bentuk terapi modalitas sering digunakan orang-orang dengan penyakit kronis, oleh karena itu dapat digunakan perawat dalam kerangka perawatan tersier dalam mencapai yang holistik, Holistic America Nurse
Association mengintegrasikan terapi komplementer seperti massage dalam intervensi keperawatan agar bermanfaat bagi pasien (Willison, Jacobs, \& Van Doorn, 2016).

Swedish Massage Therapy (SMT) merupakan suatu metode pemijatan yang dilakukan pada permukaan seluruh tubuh. Penelitian yang dilakukan oleh (Mahad, Supa'at, Idrus, \& Forsyth, 2013). menunjukkan bahwa SMT efektif dalam penurunan tekanan darah pada ibu dengan hipertensi. Pada tekanan darah sistole terjadi penurunan sebesar $12 \mathrm{mmhg}$ dan penurunan diastole sebesar $5 \mathrm{mmhg}$.

Data yang diperoleh peneliti dari Rumah Sakit An-Nisa Tangerang Oktober sampai dengan Desember didapatkan jumlah penderita hipertensi yang berobat dan dirawat di RS AnNisa sejumlah 210 pasien (Helling, Wahyudi, \& Hasanudin, 2019). Data tersebut memperlihatkan bahwa begitu besar dan membuat discharge planning dalam catatan ringkas pasien pulang. prevalensi pasien hipertensi yang masih memerlukan penatalaksanaan yang tepat. Hipertensi terjadi karena adanya peningkatan kecepatan denyut jantung dan volume sekuncup akibat susunan saraf simpati sehingga terjadi peningkatan kontraktilitas serat-serat otot jantung dengan cara vasokontriksi selektif pada organ perifer.

Jika hal ini terjadi secara terus menerus otot jantung akan menebal (hipertropi) dan mengakibatkan fungsi jantung sebagai pompa menjadi terganggu (Rizal Muttaqin, 2016).

Studi pendahuluan yang dilakukan oleh peneliti terhadap 4 
pasien dengan diagnosa Hipertensi di rawat inap RS Annisa, telah dilakukan pemeriksaan tekanan darah dan rata rata pasien memiliki tekanan darah 160/80MMhg yang artinya tergolong tinggi, pada saat ditanya upaya untuk menurukan tekanan darah selama dirumah rata rata pasien mengatakan hanya meminum obat dari dokter dan tidak melakukan terapi apapun dirumah. Peneliti menanyakan tentang terapi a Swedish Massage dan 4 orang pasien mengatakan tidak tahu sama sekali tentang terapi tersebut.

Melihat fenomena ini maka peneliti tertarik untuk menggunakan penatalaksanaan nonfarmakologis yaitu terapi relaksasi Swedish Massage untuk menurunkan tekanan darah pada pasien hipertensi, dikarenakan terapi relaksasi tersebut merupakan cara yang mudah, sederhana dan murah. Teknik ini dapat dilakukan oleh perawat dan dapat diajarkan kepada keluarga pasien

\section{Metode Penelitian}

Rancangan penelitian quasi eksperimental design: one group pre test and post test. Populasi pada penelitian ini berjumlah 60 orang. Teknik sampling yang digunakan dalam penelitian ini adalah accidental sampling. Instrument atau alat pengumpulan data yang di gunakan pada penelitian ini adalah tensi meter/ Sphygnomanometer, stetoskop dan lembar observasi untuk mencatat TD. Analisa data yang digunakan adalah Uji Beda Dua Mean Dependen (Paired test).

\section{Hasil Penelitian}

\section{A. Univariat}

Tabel 1

\begin{tabular}{llllll}
\hline Variabel & Mean & & Median & Min & Max \\
\cline { 1 - 1 } Umur & 52,77 & 52,00 & 45 & 68 \\
& & & & &
\end{tabular}

1. Berdasarkan tabel 1 distribusi frekuensi umur dari 60 responden, didapatkan hasil nilai mean usia adalah 52,77, nilai median adalah 52, nilai minimal adalah 45 dan nilai maksimal adalah 68 .

Tabel 2

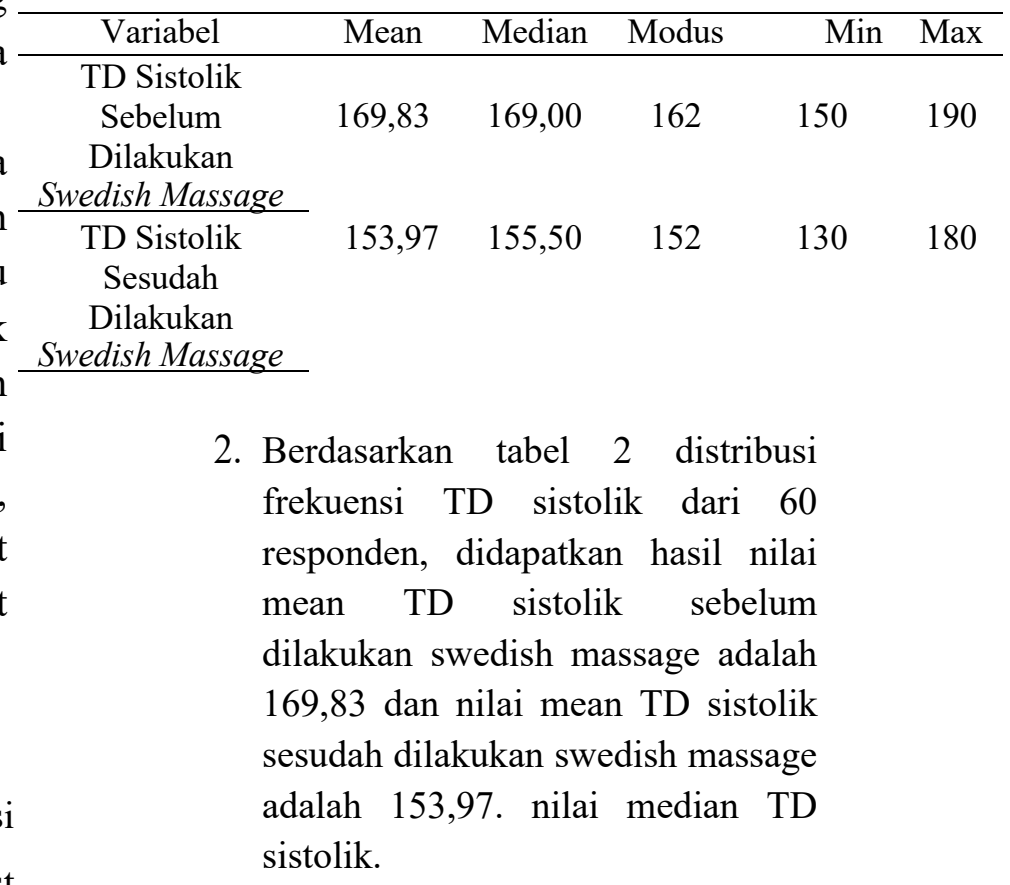

Tabel 3

\begin{tabular}{|c|c|c|c|c|c|}
\hline Variabel & Mean & Median & Modus & Min & Max \\
\hline $\begin{array}{c}\text { TD Diastolik } \\
\text { Sebelum } \\
\text { Dilakukan } \\
\text { Swedish } \\
\text { Massage }\end{array}$ & 93,42 & 92,00 & 90 & 85 & 115 \\
\hline $\begin{array}{c}\text { TD Diastolik } \\
\text { Sesudah } \\
\text { Dilakukan } \\
\text { Swedish } \\
\text { Massage } \\
\end{array}$ & 83,52 & 82,00 & 80 & 76 & 92 \\
\hline
\end{tabular}

3. Berdasarkan tabel 3 distribusi frekuensi TD diastolik dari 60 responden, didapatkan hasil nilai mean TD diastolik sebelum 
dilakukan swedish massage adalah 93,42 dan nilai mean TD diastolik sesudah dilakukan swedish massage adalah 83,52. nilai median TD diastolik sebelum dilakukan swedish massage adalah 92 dan nilai median TD diastolik sesudah dilakukan swedish massage adalah 82.

\section{B. Bivariat}

1. Hasil nilai mean TD sistolik sebelum dilakukan swedish massage adalah 169,83 dan nilai mean TD sistolik sesudah dilakukan swedish massage adalah 153,97. Terlihat nilai mean perbedaan antara pengukuran pertama dan kedua adalah 15,86. Dari hasil uji statistik di dapatkan nilai $\mathrm{P}$ Value yaitu 0,007 maka dapat disimpulkan ada pengaruh antara Swedish massage terhadap penurunan tekanan darah sistolik pada pasien hipertensi.

2. Hasil hasil nilai mean TD diastolik sebelum dilakukan swedish massage adalah 93,42 dan nilai mean TD diastolik sesudah dilakukan swedish massage adalah 83,52. Terlihat nilai mean perbedaan antara pengukuran pertama dan kedua adalah 9,9. Dari hasil uji statistik di dapatkan nilai $\mathrm{P}$ Value yaitu 0,012 maka dapat disimpulkan ada pengaruh antara pengaruh Swedish massage terhadap penurunan tekanan darah Diastolik pada pasien hipertensi.

\section{Pembahasan}

1. Pengaruh Swedish massage terhadap penurunan tekanan darah sistolik dan diastolik pada pasien hipertensi Hasil nilai mean TD sistolik sebelum dilakukan swedish massage adalah 169,83 dan nilai mean TD sistolik sesudah dilakukan swedish massage adalah 153,97. Terlihat nilai mean perbedaan antara pengukuran pertama dan kedua adalah 15,86. Dari hasil uji statistik di dapatkan nilai $\mathrm{P}$ Value yaitu 0,007 maka dapat disimpulkan ada pengaruh antara Swedish massage terhadap penurunan tekanan darah sistolik pada pasien hipertensi.

Hasil hasil nilai mean TD diastolik sebelum dilakukan swedish massage adalah 93,42 dan nilai mean TD diastolik sesudah dilakukan swedish massage adalah 83,52. Terlihat nilai mean perbedaan antara pengukuran pertama dan kedua adalah 9,9. Dari hasil uji statistik di dapatkan nilai $\mathrm{P}$ Value yaitu 0,012 maka dapat disimpulkan ada pengaruh antara pengaruh Swedish massage terhadap penurunan tekanan darah Diastolik pada pasien hipertensi.

Hasil penelitian ini sesuai dengan penelitian yang dilakukan oleh (Puspita, 2013). yang menunjukan hasil bahwa Dari hasil penelitian ini dapat diketahui bahwa rata-rata tekanan darah sistolik pre massage I sebesar $155.00 \mathrm{~mm} \mathrm{Hg}$, lalu pre massage II menurun menjadi $152.50 \mathrm{mmHg}$,

Sedangkan rata-rata tekanan darah diastolik pre massage I sebesar $91.88 \mathrm{mmHg}$, lalu pre massage II menurun menjadi $91.88 \mathrm{mmHg}$, lalu pre massage III menurun menjadi $90.00 \mathrm{mmHg}$, lalu pre massage IV naik menjadi $91.25 \mathrm{mmHg}$

Penelitian ini didukung oleh penelitian sebelumnya yang dilakukan oleh (Yuwono, Khoiriyati, \& Sari, 2016) dihasilkan adanya penurunan tekanan darah sistolik 
setelah dilakukan pijatan pada punggung pada orang usia lanjut. Penelitian serupa dilakukan oleh (Yuwono et al., 2016) yang memberikan massage pada punggung, ektremitas, kening dan kepala selama 45 menit dapat secara signifikan menurunkan tekanan sistolik.

Penelitian dan literatur yang ada menyebutkan perubahan tekanan darah, merupakan hasil dari proses relaksasi yang disebabkan dari pemberian pijat. (Cowen, Sanglard, Howard, Rogers, \& Perlin, 2015) menyatakan bahwa pijatan dapat menyebabkan vasodilatasi pembuluh darah dikarenakan adanya penurunan sistem kerja saraf simpatis dan meningkatkan kerja saraf parasimpatis sehingga pijatan dapat menurunkan vasokontriksi pembuluh darah. Selain itu pijatan akan menstimulasi untuk pelepasan histamin dimana berperan dalam vasodilatasi pembuluh darah. Hal ini didukung oleh sifat pembuluh darah yang memiliki kemampuan meregang dan mempengaruhi tekanan sistolik dan diastolik (Sherwood, 2011).

Pada penelitian ini pengukuran tekanan darah dilakukan 10 menit setelah massage. Hal ini didasari pada penelitian Koq (2010) yang melakukan pengukuran tekanan darah 10 menit setelah dilakukan massage. Namun (Bell, 2013) melaporkan waktu pembuluh darah meningkatkan sirkulasi darah pada tubuh yaitu 20 menit dan efek berlangsung selama 40 menit. Hal ini menjelaskan bahwa untuk melihat efek pemberian massage terhadap aliran darah dilakukan antara $10-20$ menit setelah massage.

Penelitian ini juga sesuai dengan penelitian yang dilakukan oleh (Octaviani \& Kartasasmita, 2018) yang mneyatakan bahwa menunjukkan bahwa nilai $\mathrm{p}$ value sebesar $0.001<0.05$. Hal ini menunjukkan bahwa terdapat efektifitas Swedish Massage Therapy (SMT) pada ibu lansia sebagai upaya penatalaksanaan hipertensi di Posyandu Lansia.

SMT sangat bermanfaat bagi penanganan hipertensi karena tindakan tersebut dapat mengatasi penyebab langsung terjadinya hipertensi. Penyebab naiknya tekanan darah bisa karena kekakuan pada dinding arteri, volume darah meningkat, atau viscositas darah meningkat. Pembuluh darah yang rileks akan menyebabkan terjadinya vasodilatasi pada pembuluh darah sehingga mengakibatkan tekanan darah akan turun (Arif Muttaqin, 2009).

Hal ini didukung oleh penelitian yang dilakukan oleh Afrila dkk menyebutkan bahwa terapi slow stroke back massage yang dikombinasikan dengan tindakan akupresur dapat menurunkan tekanan darah. Kombinasi kedua tindakan tersebut dapat memberikan ketenangan pada pasien hipertensi berupa rasa rileks pada pasien dan mengurahi sakit kepala sehingga berdampak pada peningkatan kualitas tidur pasien. Masase di area tersebut dapat merangsang sistem saraf superfisial yang akan menghambat sistem saraf simpatis sehingga tekanan darah lebih stabil dan aliran darah. Hal ini berakibat meningkatnya asupan nutrisi dan oksigen ke dalam sel (Afrila, Iskarni, \& Purwaningsih, 2015).

Pemijatan tidak hanya 
melancarkan peredaran darah, namun juga melancarkan aliran getah bening. Rangsangan yang ditimbulkan terhadap reseptor saraf juga mengakibatkan pembuluh darah melebar secara refleks sehingga melancarkan aliran darah yang sangat berpengaruh bagi kesehatan (Hadibroto \& Alam, 2006).

Hasil penelitian yang dilakukan Irmawan Andri (Nugroho et al., 2015) menyimpulkan bahwa pijat refleksi kaki bisa menurunkan tekanan darah pada tekanan sistolik dan diastolik pada hasil perhitungan menggunakan perhitungan Mann Whitney U - Test. Teknik pemijatan berdampak terhadap lancarnya sirkulasi aliran darah, menyeimbangkan aliran energi di dalam tubuh serta mengendurkan ketegangan otot. Meskipun teknik pemijatan tidak akan berdampak banyak pada penderita hipertensi berat, tetapi beberapa penelitian telah membuktikan bahwa massase dapat menurunkan tekanan darah pada penderita hipertensi ringan dan sedang (Dalimartha, 2008).

Massage kaki menimbulkan relaksasi yang dalam sehingga meringankan kelelahan jasmani dan rohani dikarenakan sistem saraf simpatis mengalami penurunan aktivitas yang akhirnya mengakibatkan turunnya tekanan darah (Kaplan \& Norton, 2006) Massagse merupakan teknik integrasi sensori yang mempengaruhi aktivitas sistem saraf otonom. Apabila seseorang mempersepsikan sentuhan sebagai stimulus rileks maka akan muncul respon relaksasi (Potter, Perry, Hall, \& Stockert, 2009).

Penelitian lain yang mendukung hasil penelitian yaitu efektifitas pemberian terapi bekam dan terapi pijat refleksi terhadap tekanan darah pada penderita hipertensi. Penelitian ini dilakukan oleh Rohatami dkk tahun 2015 dengan hasil terapi bakam dan terapi pijat refleksi terbukti baik digunakan untuk terapi alternatif dalam mengontrol tekanan darah agar tetap stabil bagi penderita hipertensi (Rohatami, Maliya, \& Ambarwati, 2015)

Terapi pijat refleksi merupakan terapi pijat yang sudah terkenal di negara Indonesia. Terapi pijat refleksi dan Terapi Swedish Massage (SMT) bertujuan sama yaitu untuk membuat pasien lebih rileks dan nyaman. Rasa relaksasi yang dihasilkan oleh stimulasi taktil di jaringan tubuh berdampak pada penurunan produksi kortisol yang diakibatkan oleh peningkatan sekresi corticotropin dari HPA. Setelah tubuh rileks maka otak mengeluarkan serotonin yang berperan dalam perubahan fisiologis pada tubuh yaitu menyebabkan dilatasi pembuluh darah kapiler dan arteriol sehingga mikrosirkulasi pembuluh darah membaik. Efek membaiknya mikrosirkulasi pembuluh darah yaitu terjadi relaksasi pada otot-otot yang kaku serta akibat vasodilatasi pada pembuluh darah akan menurunkan tekanan darah secara stabil (Guyton \& Bays, 2007).

Penelitian terbaru yang mendukung penelitian adalah penelitian yang dilakukan oleh (Arianto, Iriani, \& Arthur, 2019). Penelitian tersebut bertujuan untuk membuktikan bahwa terapi pijat refleksi telapak kaki terhadap perubahan tekanan darah pada penderita hipertensi. Uji statistik yang digunakan adalah uji Wilcoxon 
dengan asil nilai signifikansi 0.001 yang artinya pijat refleksi telapak kaki berpengaruh terhadap perubahan tekanan darah pada penderita hipertensi (Bangun, Tandiono, \& Arianto, 2018).

\section{BIBILIOGRAFI}

Afrila, Nel, Iskarni, Paus, \& Purwaningsih, Endah. (2015). Main Article Content.

Arianto, Agung, Iriani, Tuti, \& Arthur, Riyan. (2019). Hubungan Komunikasi Instruksional Dengan Hasil Belajar Ilmu Ukur Tanah Di Smk Negeri 1 Jakarta. Jurnal Pensil: Pendidikan Teknik Sipil, 8(1), 31-39.

Bangun, Hakim, Tandiono, Steven, \& Arianto, Anayanti. (2018). Preparation and evaluation of chitosantripolyphosphate nanoparticles suspension as an antibacterial agent. Journal of Applied Pharmaceutical Science, 8(12), 147-156.

Bell, Ronald Percy. (2013). The proton in chemistry. Springer Science \& Business Media.

Cowen, Leah E., Sanglard, Dominique, Howard, Susan J., Rogers, P. David, \& Perlin, David S. (2015). Mechanisms of antifungal drug resistance. Cold Spring Harbor Perspectives in Medicine, 5(7), a019752.

Dalimartha, Setiawan. (2008). Atlas tumbuhan obat Indonesia (Vol. 2). Niaga Swadaya.

Davis, Alan L., Carcillo, Joseph A., Aneja, Rajesh K., Deymann, Andreas J., Lin, John C., Nguyen, Trung C., Okhuysen-Cawley, Regina S., Relvas, Monica S., Rozenfeld, Ranna A., \& Skippen, Peter W. (2017). American College of Critical Care Medicine clinical practice parameters for hemodynamic support of pediatric and neonatal septic shock. Critical Care Medicine, 45(6), 1061-1093.

Depkes, R. I. (2016). Peraturan pemerintah Republik Indonesia nomor 72 tahun 2016 tentang standar pelayanan kefarmasian di rumah sakit. Departemen Kesehatan RI: Jakarta.

Guyton, John R., \& Bays, Harold E. (2007). Safety considerations with niacin therapy. The American Journal of Cardiology, 99(6), S22-S31.

Hadibroto, Iwan, \& Alam, Syamsir. (2006). Seluk Beluk Pengobatan Alternatif dan Komplementer. Jakarta: PT Bhuana Ilmu Populer.

Helling, Lydia Salvina, Wahyudi, Endang, \& Hasanudin, Hasanudin. (2019). Siremis: Sistem Informasi Rekam Medis Puskesmas Kecamatan Matraman Jakarta. Intensif: Jurnal Ilmiah Penelitian Dan Penerapan Teknologi Sistem Informasi, 3(2), 116-129.

Intarti, Wiwit Desi, \& Khoriah, Siti Nur. (2018). Faktor-Faktor Yang Mempengaruhi Pemanfaatan Posyandu Lansia. Journal of Health Studies, 2(1), 110-122.

Kaplan, Robert S., \& Norton, David P. (2006). Alignment: Using the balanced scorecard to create corporate synergies. Harvard Business Press.

Mahad, Farah Diana, Supa'at, Abu Sahmah M., Idrus, Sevia Mahdaliza, \& Forsyth, David. (2013). Analyses Of Semiconductor Optical Amplifier (SOA) Four-Wave Mixing (FWM) For Future All-Optical Wavelength Conversion. Optik, 124(1), 1-3.

Muttaqin, Arif. (2009). Pengantar Asuhan Keperawatan Dgn Gangguan Sistem Kardiovaskular. Penerbit Salemba.

Muttaqin, Rizal. (2016). Kemandirian Dan Pemberdayaan Ekonomi Berbasis 
Pesantren (Studi Atas Peran Pondok Pesantren Al-Ittifaq Kecamatan Rancabali Kabupaten Bandung Terhadap Kemandirian Eknomi Santri Dan Pemberdayaan Ekonomi Masyarakat Sekitarnya). JESI (Jurnal Ekonomi Syariah Indonesia), 1(2),6594.

Nugroho, Rininta Putri, Zuiderwijk, Anneke, Janssen, Marijn, \& de Jong, Martin. (2015). A comparison of national open data policies: Lessons learned. Transforming Government: People, Process and Policy.

Octaviani, Cecilia, \& Kartasasmita, Sandi. (2018). Pengaruh Konsep Diri Terhadap Perilaku Konsumtif Pembelian Produk Kosmetik Pada Wanita Dewasa Awal. Jurnal Muara Ilmu Sosial, Humaniora, Dan Seni, 1(2), 126-133.

Olney, James. (2015). Tell me Africa: An approach to African literature. Princeton University Press.

Potter, Patricia A., Perry, Anne Griffin Ed, Hall, Amy Ed, \& Stockert, Patricia A. (2009). Fundamentals of nursing. Elsevier mosby.

Puspita, Dinta. (2013). Faktor-Faktor Yang Berhubungan Dengan Kelelahan Mata Pada Operator Sistem Informasi Akademik Terpadu (SIAT) Program Studi Di Universitas Negeri Gorontalo Tahun 2013. Skripsi, 1(811409048).

Robinson, James E., Hastie, Kathryn M., Cross, Robert W., Yenni, Rachael E., Elliott, Deborah H., Rouelle, Julie A.,
Kannadka, Chandrika B., Smira, Ashley A., Garry, Courtney E., \& Bradley, Benjamin T. (2016). Most Neutralizing Human Monoclonal Antibodies Target Novel Epitopes Requiring Both Lassa Virus Glycoprotein Subunits. Nature Communications, 7(1), 1-14.

Rohatami, Oktarina, Maliya, Arina, \& Ambarwati, Rina. (2015). Efektivitas Pemberian Terapi Bekam Dan Terapi Pijat Refleksi Terhadap Tekanan Darah Pada Penderita Hipertensi. Universitas Muhammadiyah Surakarta.

Seke, Prisilia Alva, Bidjuni, Hendro, \& Lolong, Jill. (2016). Hubungan Kejadian Stres Dengan Penyakit Hipertensi Pada Lansia Di Balai Penyantunan Lanjut Usia Senjah Cerah Kecamatan Mapanget Kota Manado. Jurnal Keperawatan, 4(2).

Sherwood, Dennis. (2011). Seeing the forest for the trees: a manager's guide to applying systems thinking. Nicholas Brealey International.

Willison, Hugh J., Jacobs, Bart C., \& Van Doorn, Pieter A. (2016). Guillainbarre syndrome. The Lancet, 388(10045), 717-727.

Yuwono, Podo, Khoiriyati, Azizah, \& Sari, Novita Kurnia. (2016). Pengaruh Terapi Pijat Refleksi Kaki Terhadap Ankle Brachial Index (Abi) Pada Pasien Diabetes Melitus Tipe 2. MOTORIK Jurnal Ilmu Kesehatan, 10(20).

\section{Copyright holder:}

Tri Widyaningrum (2020)

\section{First publication right:}

Jurnal Health Sains

This article is licensed under: 